\title{
Simulation of electrical properties of quartz crystal microbalance using multi-resonance thickness-shear mode technique
}

- Tran Thi Minh Thu

- Tran Huy Thong

- Duong Tan Phuoc

- Ngo Vo KeThanh

- Nguyen Dang Giang

- Truong Huu Ly

- Nguyen Ngoc Viet

IC Design Research and Education Center, VNU-HCM

(Received on $2^{\text {nd }}$ January 2016, accepted on $2^{\text {nd }}$ December 2016)

\section{ABSTRACT}

The use of quartz crystal microbalance (QCM) in chemistry, biophysics, microbiology and electronics has grown tremendously in recent years. In this paper, the properties of a QCM sensor (a system include QCM device and viscoelastic medium) operating in the range of 5 $\mathrm{MHz}$ to $35 \mathrm{MHz}$ of Multi-resonance ThicknessShear Mode (MTSM, $n=1,3,5,7)$ are described. We calculate the changes both in resonant frequencies and attenuation of the QCM. The penetration depth of the shear waves propagating from quartz into loaded thin film varies in different values due to the harmonics,

from which we infer the properties of the loaded thin film. The multi-harmonic operation of QCM was presented to collect the information of the loaded thin film on QCM's electrode. This enables a "virtual slicing technique" because a harmonic relates to a different penetration depth even with the same material. The theoretical analysis of MTSM has been developed to model and simulate the signature of the sensor responses at harmonic frequencies. The signatures of the evaporation-induced deposition processes were investigated by studying the effect of the thickness and stiffness of the medium.

Key words: Quartz crystal microbalance, Multi-resonance Thickness-Shear Mode

\section{INTRODUCTION}

The Quartz Crystal Microbalance (QCM) is a very sensitive device that measures the mass by detecting the change in vibrating frequency of the quartz crystal. The change in the frequency and attenuation of the crystal is proportional to the added mass and the viscosity of the medium. To design QCM usable in damping media like a sensor, simulation tools to predict its behavior is very useful.

There are a large number of published papers describing the interaction of proteins and peptides with polymeric and planar thin films (Briseno et al., 2001; Yamashitaet al., 2001; Fant et al., 2002; Hibbert et al., 2002; Linder et al., 2002; Park et al., 2002; Takada et al., 2002; Andersson et al., 2002a; Forzani et al., 2003; Hamada et al.,2003; Plunkett et al., 2003; Haynie et al., 2004; Heuberger et al., 2004; Lin et al., 2004; Lojou and Bianco, 2004; Notley et al., 2004; Welle, 2004; Evans-Nguyen and Schoenfisch, 2005) using QCM as a biosensor.

\section{Trang 194}


QCM combined with thin interfacial chemistries has been used to measure the transfer efficiency of a HSA-octadecylamine LangmuirBlodgett (LB) film from the subphase interface to the gold electrode surface (Yin et al., 2005), confirming the protein resistance of poly(ethyleneglycol) (PEG) SAMs (Menz et al., 2005) and supported bilayers of eggphosphatidylcholine (PC) lipids (Glasmastar et al., 2002). QCM was also used to characterize the adsorption kinetics of unfolded and folded low molecular weight proteins to hydrophobic SAM surfaces (Otzen et al., 2003). He et al. (2002) monitored the assembly process of poly(diallyldimethylammonium) and haemoglobin films on graphite electrodes and other substrates. Dupont-Filliard et al. (2004a) investigated the adsorption of avidin onto a biotinylated polypyrrole film. Zhou et al. (2004) used a number of techniques to investigate human IgG adsorption onto a hydrophobized gold surface and found the QCM-D technique to correctly detect the conformational change in the $\mathrm{IgG}$ leading to a difference in the effective protein thickness. Li et al. (2003a) employed a polystyrenesulfonate layer on an electropolymerized film to quantitatively determine IgG concentration in the range 1.7-200 $\mathrm{mg} / \mathrm{mL}$.

In Vietnam, studying QCM has not been invested broadly. International training institute for materials science (ITIMS, Hanoi University of Science and Technology) had fabricated QCM sucessfully but applicating QCM as a biosensor has not been established.

This paper introduces the model which provides the evaporation-induced deposition processes of the film loaded on quartz by varying the thickness and stiffness of the medium. The main objective of the work is to simulate of MTSM sensor loaded with viscoelastic (VE) mediums but the geometrical (thickness) and the mechanical (density) properties of this medium will change following the evaporation- induced deposition processes.

Using the boundary condition, Maxwell's model and the equivalent circuit, we can find the attenuation, frequency shift which contain the information of the electrical properties by calculating by Matlab software. Electrical characteristics of the QCM sensor are depicted.

\section{THEORY}

A QCM consists of a thin AT cut - quartz crystal disk with two electrodes of the quartz (Fig.1) [3]. Due to the piezoelectric properties and crystalline orientation of the quartz, a voltage applied to these electrodes results in a shear deformation of the crystal.

The resonant frequency $\mathrm{f}_{0}$ of the quartz is given by:

$$
f_{0}=N \frac{v_{q}}{2 d}
$$

Where:

$\mathrm{N}=1,3,5,7 \ldots$

$\mathrm{d}$ : is the thickness of the QCM

$v_{\mathrm{q}}$ : is the velocity of the acoustic wave propagation in quartz.

Sauerbrey [1] showed that the frequency change caused by an addition mass on that resonator is presented by:

$$
\frac{\Delta f_{0}}{\Delta m}=-\frac{2 f_{0}^{2}}{A \sqrt{\rho_{q} \mu_{q}}}
$$

Which means that the variation in resonant frequency $\left(\Delta f_{0}\right)$ in terms of the mass variation $(\Delta \mathrm{m})$ is proportional to the square of the resonant frequency $\left(f_{0}\right)$ and inversely proportional to the electrode area (A), the density $\left(\rho_{q}\right)$ and the viscosity $\left(\mu_{q}\right)$ of liquid. In other words, higher resonant frequency and smaller electrode area will result in a higher sensitivity. 


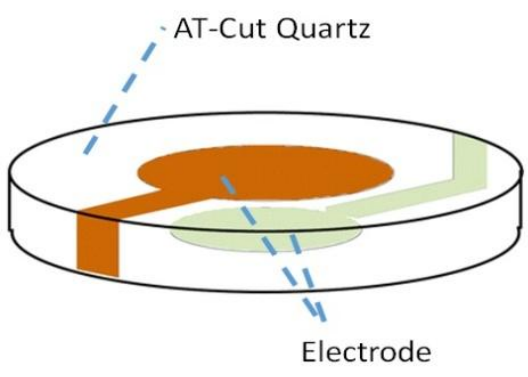

Fig. 1. QCM device structure

Sauerbrey's relation is extended for use with elastic films by Miller and Bolef [4] and simplified by Lu and Lewis [5]. Until recently, excessive viscous loading was believed to prohibit the use of the QCM in liquids. In fact, this is still possible and the response of the QCM is sensitive to mass changes at the solid-solution interface.

When the QCM operates in a solution, the frequency is decreased depending on the viscosity and the density of the solution. This problem was first studied by Glassford [6], and later by Kanazawa and Gordon [2]. Kanazawa realized that the solution properties influenced the crystal resonance frequency and the resonance frequency shift is calculated by:

$$
\Delta f_{0}=-f_{0}^{3 / 2} \sqrt{\frac{\eta_{l} \rho_{l}}{\pi \eta_{q} \mu_{q}}}
$$

Where $\eta_{l}$ and $\rho_{l}$ are the viscosity and density of liquid contact with the electrode and $\eta_{q}, \rho_{q}$ are the viscosity and density of quartz.

The measured frequency shift is changed by the density and the viscosity of the liquid. When the QCM works in a liquid, the maximum displacement happens on the surface. This makes the device sensitive to a superficially added mass which causes a change in the resonant frequency. To use QCM as a biosensor, the crystal is coated with a thin layer antigen and is used to detect antibodies.

Fig. 2 depicts the geometry of the QCM loaded by a viscoelastic thin film.

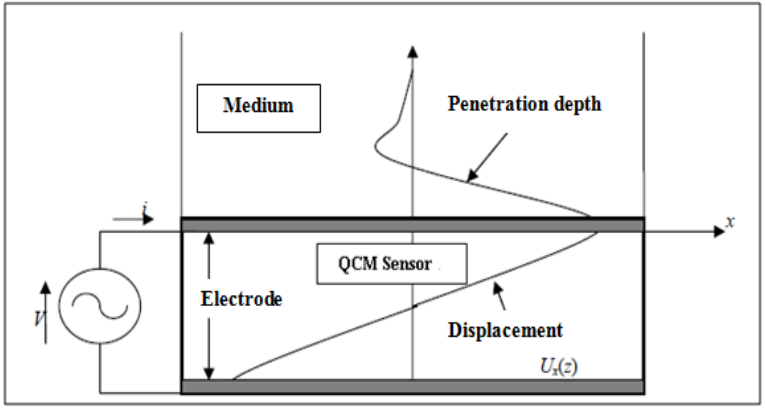

Fig. 2. Physical description of a QCM loaded on one side by a viscoelastic thin film

QCM devices can be operated not only at fundamental harmonic but also at higher harmonic. As higher harmonics are applied, the frequency shift and attenuation represent the mechanical properties of the loaded thin fim of the different distance from the surface of quartz due to the different penetration depth of the acoustic wave through the medium. Fig. 3 shows the principles of this concept [7]. For example, if the medium has different mechanical properties through the thickness, then it can be observed by analyzing the different responses of the MTSM sensor at each harmonics.

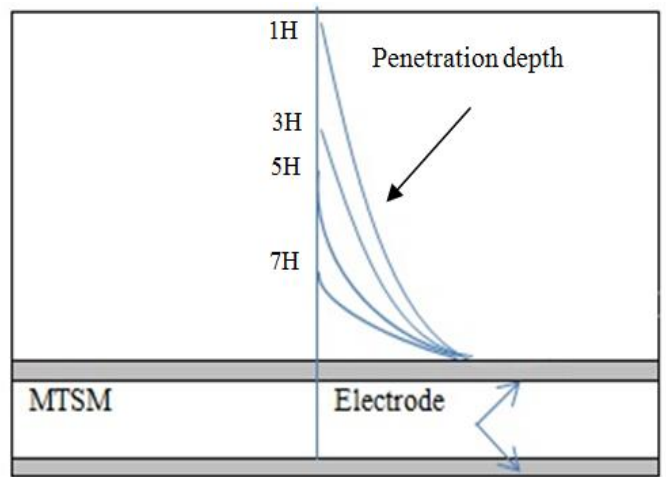

Fig. 3. A model of the MTSM sensor [7]

\section{METHOD}

QCM or MTSM sensor was used as a biosensor and the application process is the evaporation-induced deposition process whereby atoms or molecules in a liquid state gain sufficient energy to enter the gaseous state and leaving a thin-film. Especially, during the

\section{Trang 196}


evaporation-induced deposition process of biological samples, there are two major processes involved: evaporation of a solution and deposition of proteins on the surface of the sensor substrate.

Since the response of the MTSM depends on the interfacial processes, such as mass accumulation (density) or changes in mechanical and geometrical properties (elastic stiffness, viscosity, and thickness). In this paper, only the thickness (represent to geometrical properties) and density (represent to mechanical properties) were studied and analyzed using theoretical and simulation method. The output signals are the frequency shifts, the attenuation and the penetration depth at harmonics.

Fig. 4 shows the evaporation-induced deposition process of viscoelastic medium on the sensor surface.

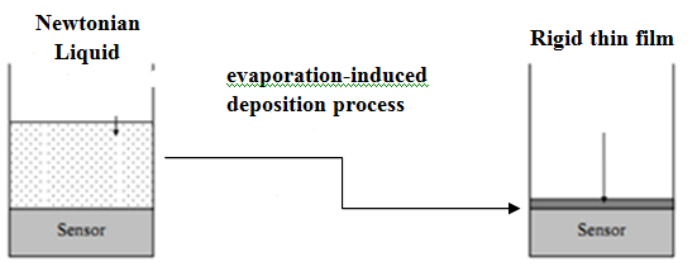

Fig. 4. A typical evaporation-induced deposition process of viscoelastic medium
The proposed geometry of the composite QCM/viscoelastic mediums by [2] is used in this study (Fig. 5). The mathematics using in this geometry is simple.

The origin is at the interface between the quartz and the film. The film is characterized by its density $\rho_{\mathrm{f}}$, its shear modulus $\mu_{\mathrm{f}}$ and its viscosity $\eta_{\mathrm{f}}$. The quartz parameters include its density $\rho_{\mathrm{q}}$, its shear modulus $\mathrm{c}_{66}$, its appropriate piezoelectric constant $\mathrm{e}_{26}$, its relative permittivity $\varepsilon_{22}$ and its viscosity $\eta_{\mathrm{q}}$. For purpose in fabrication, we have chosen the series of resonance of unloaded quartz at exactly $5 \mathrm{MHz}$.

The shear waves in both the quartz and the over layer are the sum of a wave travelling in the $+y$ direction and another in the -y direction and have the form $\mathrm{e}^{\mathrm{i} \omega \mathrm{t}}$. For the quartz, the amplitude of the wave travelling in the $+\mathrm{y}$ direction is $\mathrm{A}$ and in the $-y$ direction is B. Similarly, the wave amplitudes in the over layer are $\mathrm{C}$ and $\mathrm{D}$. The wave vector for the shear wave in the quartz is $\mathrm{k}_{\mathrm{q}}$ and the over layer is $\mathrm{k}_{\mathrm{f}}$. The shear wave spreading in the quartz have the following forms:

$U(y, t)=\left(A e^{-j k_{f}(y-L)}+B e^{j k_{f}(y-L)}\right) e^{j \omega t}$

and the over layer:

$$
U(y, t)=\left(C e^{j k_{q} y}+D e^{-j k_{q} y}\right) e^{j \omega t}
$$

Air

\begin{tabular}{|c|c|}
\hline Load & 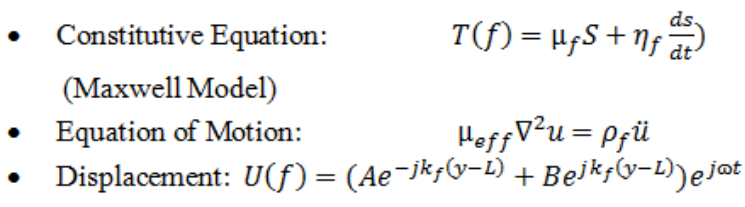 \\
\hline Quartz & $\begin{array}{l}\text { - Constitutive Equation: } T=c_{q} S-e_{q} E \\
\qquad D=e S+\varepsilon E \\
\text { (Maxwell Model) } \\
\text { - Equation of Motion: } \mu_{q} \nabla^{2} u=\rho_{q} \ddot{u} \\
\text { - Displacement: } U(q)=\left(C e^{j k_{q} y}+D e^{\left.-j k_{q} y\right)}\right) e^{j \omega t} \\
\text { - } \\
\text { Electrical Potential: } \phi(q)=\left(\frac{e_{26}}{\varepsilon_{22}} u(q)+E y+F\right) e^{j \omega t}\end{array}$ \\
\hline
\end{tabular}

Fig. 5. Geometry used for the QCM analysis 


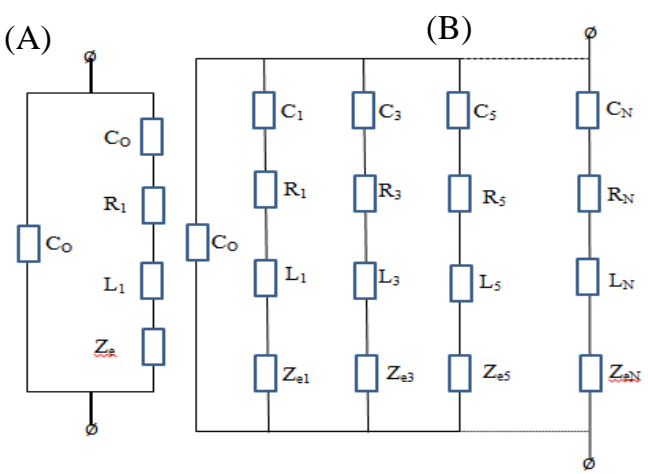

Fig. 6. Equivalent circuit models to describe the near resonant electrical characteristics of the MTSM resonator with VE film coatings [7]: (A) Fundamental - resonance harmonic, (B) Multi-resonance harmonics

Using the boundary condition, Maxwell's model and the equivalent circuit, we calculated the attenuation $(\alpha)$ and the resonant frequency $\operatorname{shift}(\Delta \mathrm{f})$ of MTSM sensor as follows [7]:

$$
\alpha=S_{21}=20 \log _{10}\left(\left|\frac{100}{100+Z_{t}}\right|\right)
$$

Where:

$$
Z_{t}=\frac{Z_{s} Z_{0}}{Z_{s}+Z_{0}}, Z_{s}=R_{N}+j \omega L_{N}+\frac{1}{j \omega C_{N}}+Z_{e}
$$

$$
\begin{gathered}
Z_{0}=\frac{1}{j \omega C_{0}}, C_{0}=\frac{\varepsilon_{22} A}{h_{S}}, C_{N}=\frac{8 K^{2} C_{0}}{N \pi^{2}}, L_{N}=\frac{1}{\omega^{2} C_{N}}, \\
R_{N}=\frac{\eta_{q}}{\mu_{q} C_{N}}
\end{gathered}
$$

Where $A$ and $h_{s}$ are the area of the electrode and the thickness; $\varepsilon 22, \mu \mathrm{q}$, and $\eta \mathrm{q}$ are the dielectric permittivity, shear stiffness and effective viscosity of the MTSM sensor, respectively. $Z t$ indicates the total electrical impedance of the MTSM. S21 means the forward transmission parameter.

The relative change in the resonant frequency $(\Delta f)$ is the real part of this equation (9),

$$
\Delta \mathrm{f}=\mathrm{f}_{0 \mathrm{~N}} \cdot \mathfrak{R}\left[\frac{1}{\mathrm{~N} \pi} \tan ^{-1}\left(\frac{-\mathrm{k}_{\mathrm{f}}\left(\mu_{\mathrm{f}}+\mathrm{j} \omega \eta_{\mathrm{f}}\right) \tan \left(\mathrm{k}_{\mathrm{f}} \mathrm{h}\right)}{\mu_{\mathrm{q}} \mathrm{k}_{\mathrm{q}}}\right)\right]
$$

\section{RESULTS AND DISCUSSION}

We have developed a program using Matlab software to trace out the effect of change in the thickness and density on the MTSM response and effect of changes in density on the MTSM response. The mechanical properties of AT-cut quartz were shown on Table 1.

Table 1. Mechanical properties of AT-cut quartz

\begin{tabular}{|c|c|c|c|c|c|}
\hline $\begin{array}{c}\text { Thickness } \\
(\mathrm{m})\end{array}$ & $\begin{array}{c}\text { Density } \\
(\mathrm{g} / \mathrm{cc})\end{array}$ & $\begin{array}{c}\text { Shear storage } \\
\text { modulus } \\
(\mathrm{Pa})\end{array}$ & $\begin{array}{c}\text { Viscosity } \\
\left(\mathrm{kg} \cdot \mathrm{m}^{-1} \cdot \mathrm{sec}^{-1}\right)\end{array}$ & $\begin{array}{c}\text { Dielectricity } \\
\text { constant } \\
\left(\mathrm{S} 4 / \mathrm{kg} \cdot \mathrm{m}^{3}\right)\end{array}$ & $\begin{array}{c}\text { Piezoelectric } \\
\text { constant } \\
\left(\mathrm{S} / \mathrm{m}^{2}\right)\end{array}$ \\
\hline $334 \times 10^{-6}$ & 2.648 & $2.947 \times 10^{10}$ & $9.2475 \times 10^{-3}$ & $3.982 \times 10^{-11}$ & $9.53 \times 10^{-2}$ \\
\hline
\end{tabular}

\section{Effect of film's thickness}

In this section, evaporation-induced deposition process of the films has been simulated by only varying the thickness. The input mechanical properties of the thin film loaded were shown in Table 2.

In this case, the film is a Newtonian liquid because of the low concentration of the solutes in the solution. The stiffness was equal to zero and the density was $1000 \mathrm{~kg} / \mathrm{m}^{3}$. Due to the evaporation process of the solvent through the liquid surface the thickness of the sample changes. Therefore, only the thickness of the sample was varied from 10 ? $\mathrm{m}$ down to $100 \mathrm{~nm}$ for the simulations. Fig. 7, 8, 9 show the simulation of the MTSM sensor of harmonic responses for liquids of different viscosity. Gray arrows in each graph show the direction of changes in the thickness decreasing during the evaporation process.

Fig. 7 show the response of the MTSM sensor when the viscosity of the VE load is the same as water at $0.001 \mathrm{~kg} / \mathrm{ms}$. As the evaporation of the solvent is continuous, the concentration of the solute starts to increase and the increment of solute affects the viscosity of the solution to rise. Fig. 8, 9 show the response of MTSM sensor with the higher viscosity, 0.01 and $0.1 \mathrm{~kg} / \mathrm{ms}$.

\section{Trang 198}


Table 2. Mechanical properties of the film

\begin{tabular}{|c|c|c|c|c|}
\hline & Density $\left(\mathrm{kg} / \mathrm{m}^{3}\right)$ & Viscosity $(\mathrm{kg} / \mathrm{m} . \mathrm{s})$ & Stiffness $(\mathrm{Pa})$ & Thickness $(\mathrm{m})$ \\
\hline Fig. 7 & 1000 & 0.1 & 0 & $10^{-7}-10^{-5}$ \\
\hline Fig. 8 & 1000 & 0.01 & 0 & $10^{-7}-10^{-5}$ \\
\hline Fig. 9 & 1000 & 0.001 & 0 & $10^{-7}-10^{-5}$ \\
\hline
\end{tabular}

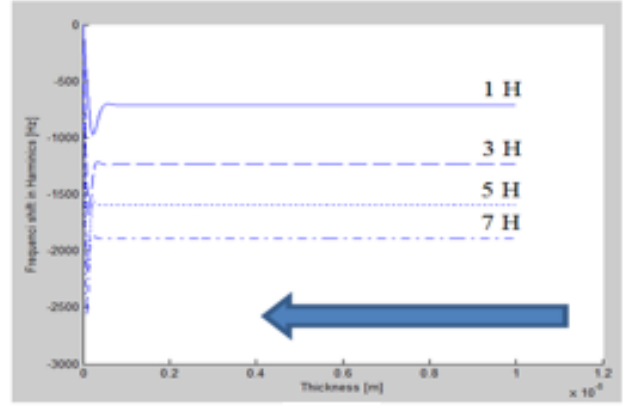

(A)

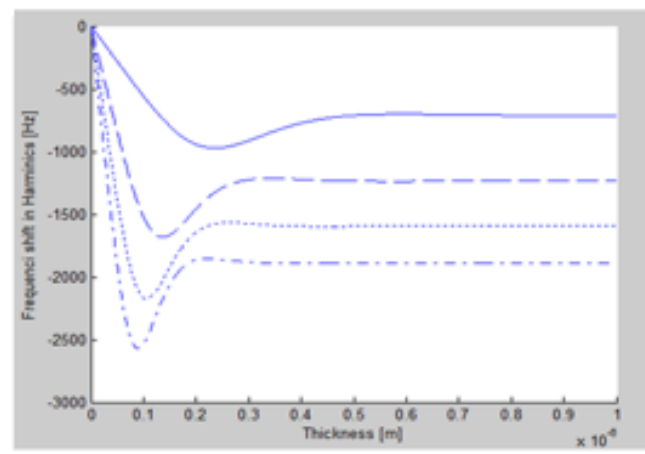

(C)

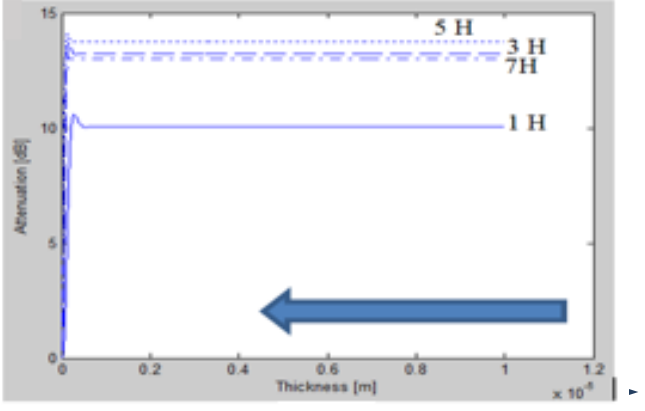

(B)

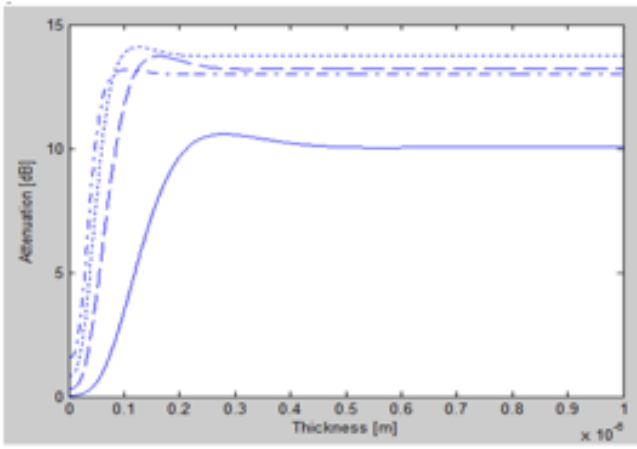

(D)

Fig. 7. Effect of the changes in thickness to MTSM response with the viscosity is $0.001 \mathrm{~kg} / \mathrm{ms}$ : (A) relation between frequency shift and thickness with range of $0-1.2 \times 10^{-5} \mathrm{~m}$; (B) relation between attenuation and thickness with range of $0-1.2 \times 10^{-5} \mathrm{~m}$; (C) relation between frequency shift and thickness with range of $0-1.2 \times 10^{-6}$; (D) relation between attenuation and thickness with range of $0-1.2 \times 10^{-6} \mathrm{~m}$

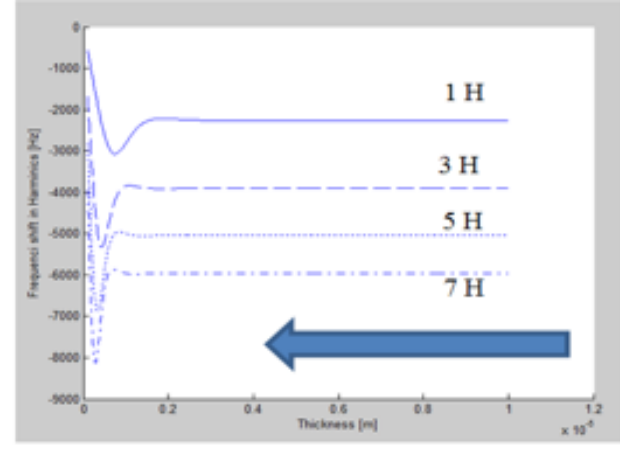

(A)

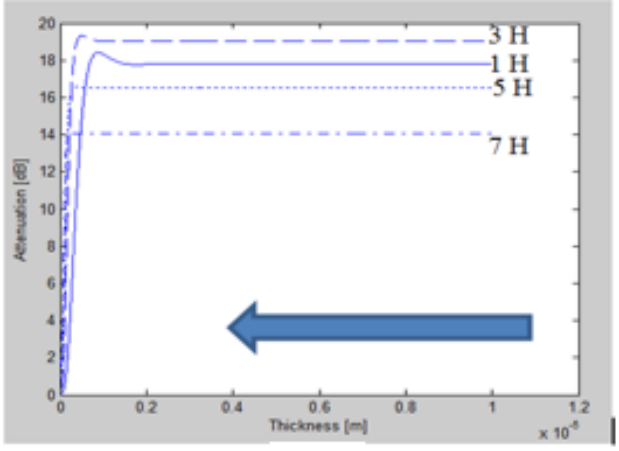

(B)

Fig. 8. Effect of the changes in thickness (from 0 to $10^{-5} \mathrm{~m}$ ) to MTSM response: frequency shift (A) and Attenuation (B) with the viscosity is 0.01 


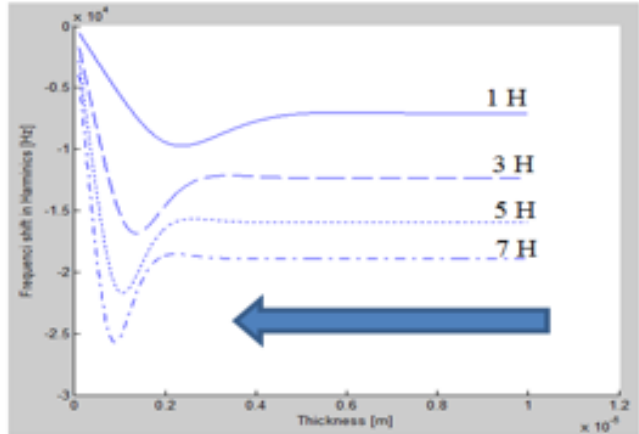

(A)

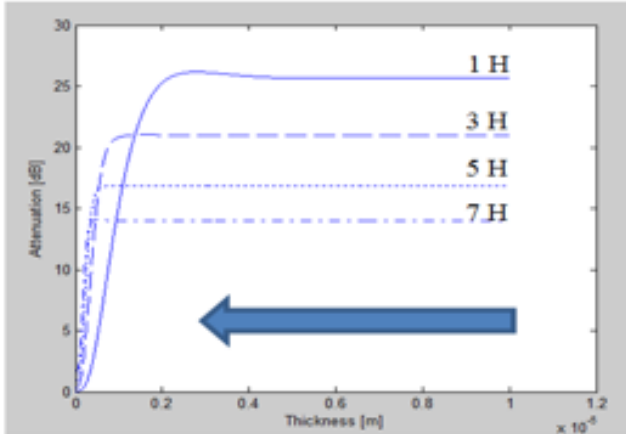

(B)

Fig. 9. Effect of the changes in thickness to MTSM response with the viscosity is 0.01: (A) relation between frequency shift and thickness with range of $0-1.2 \times 10^{-5} \mathrm{~m}$; (B) relation between attenuation and thickness with range of $0-1.2 \times 10^{-5} \mathrm{~m}$; (C) relation between frequency shift and thickness with range of $0-1.2 \times 10^{-6}$; (D) relation between attenuation and thickness with range of $0-1.2 \times 10^{-6} \mathrm{~m}$

The simulation results on Fig. 7, 8, 9 show the same trend. Firstly, it starts with stabilized response when the thickness is much larger than the penetration depth. Secondly, as the thickness of the VE film reaches close to couple of the penetration depth, the response of MTSM sensor starts to oscillate in both relative changes in resonant frequency $(\Delta \mathrm{f})$ and attenuation $(\alpha)$. Finally, when the thickness of the VE film becomes smaller than the penetration depth, it shows the both Sauerbrey mass effect and Kanazawa viscous effect: decrease in both relative $\Delta \mathrm{f}$ and $\alpha$, as the thickness becomes smaller.

Table 3 shows the penetration depth $(\delta)$ of acoustic shear waves in each simulation.

Table 3. Penetration depths of the acoustic shear waves of $05 \mathrm{MHz}$ frequency in Newtonian liquid with various viscosities

\begin{tabular}{|c|c|c|c|}
\hline & $\begin{array}{c}\delta(\mathrm{nm}) \eta \\
=0.001 \mathrm{~kg} / \mathrm{ms} \\
(\text { water })\end{array}$ & $\begin{array}{c}\delta(\mathrm{nm}) \\
\eta=0.01 \\
\mathrm{~kg} / \mathrm{ms}\end{array}$ & $\begin{array}{c}\delta(\mu \mathrm{m}) \eta \\
=0.1 \mathrm{~kg} / \mathrm{ms} \\
(\text { glycerol })\end{array}$ \\
\hline $1 \mathrm{H}$ & 252.31 & 797.88 & 2.5231 \\
\hline $3 \mathrm{H}$ & 145.67 & 460.66 & 1.4567 \\
\hline $5 \mathrm{H}$ & 112.84 & 356.82 & 1.1284 \\
\hline $7 \mathrm{H}$ & 95.365 & 301.57 & 0.95365 \\
\hline
\end{tabular}

Trang 200

\section{Effect of film's density}

In this section, the evaporation-induced deposition process of biological films has been simulated by varying the density of the film. The mechanical properties of Newtonian Liquid was shown in Table 4.

In this case, the density changed from 500 to $2000 \mathrm{~kg} / \mathrm{m}^{3}$ for the simulation to be in the realistic range.

Fig. 10, 11, 12 show the effect of density in the response of the MTSM sensor. The results showed either a typical Sauerbrey effect (effect of mass due to change the density) or the Kanazawa effect (effect of viscous due to change the density).

In Fig. 10 and 11 the MTSM sensor treats the VE film as a load with an infinite thickness film and the Kanazawa viscous effect is showed in the graphs. As the density of the VE film increase, the relative changes in $\Delta \mathrm{f}$ and $\alpha$ are also increased. As an acoustic signature, the attenuation of the higher harmonic responses, such as $5^{\text {th }}$ and $7^{\text {th }}$ harmonics, seems not sensitive to the changes in the density of the medium, and the attenuation of the lower harmonics, such as $1^{\text {st }}$ and $3^{\text {rd }}$ harmonics, shows the density effect (as density increases attenuation also increases due to the Kanazawa viscous effect). 
Table 4. Mechanical properties of film

\begin{tabular}{|c|c|c|c|c|}
\hline & Density $\left(\mathrm{kg} / \mathrm{m}^{3}\right)$ & Viscosity $(\mathrm{kg} / \mathrm{m} . \mathrm{s})$ & Stiffness $(\mathrm{Pa})$ & Thickness $(\mathrm{m})$ \\
\hline Fig. 10 & $500-2000$ & 0.1 & 108 & $10^{-6}$ \\
\hline Fig. 11 & $500-2000$ & 0.01 & 105 & $10^{-5}$ \\
\hline Fig. 12 & $500-2000$ & 0.001 & 0 & $10^{-4}$ \\
\hline
\end{tabular}

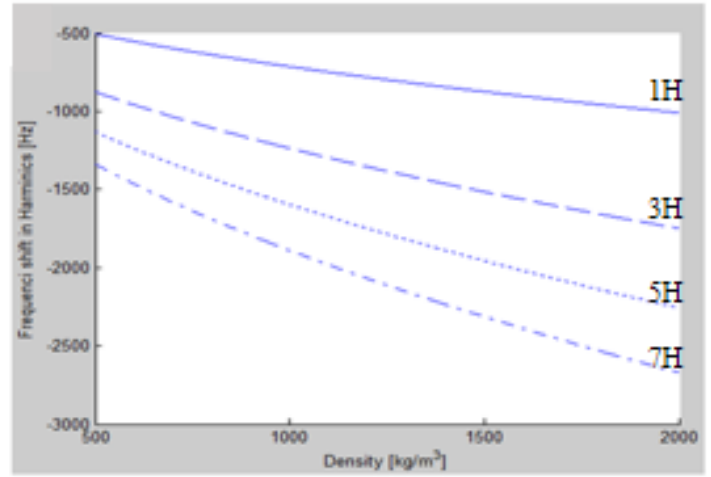

(A)

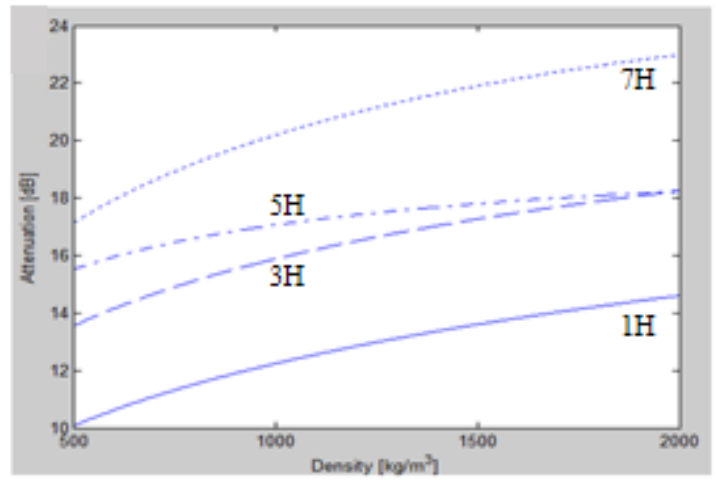

(B)

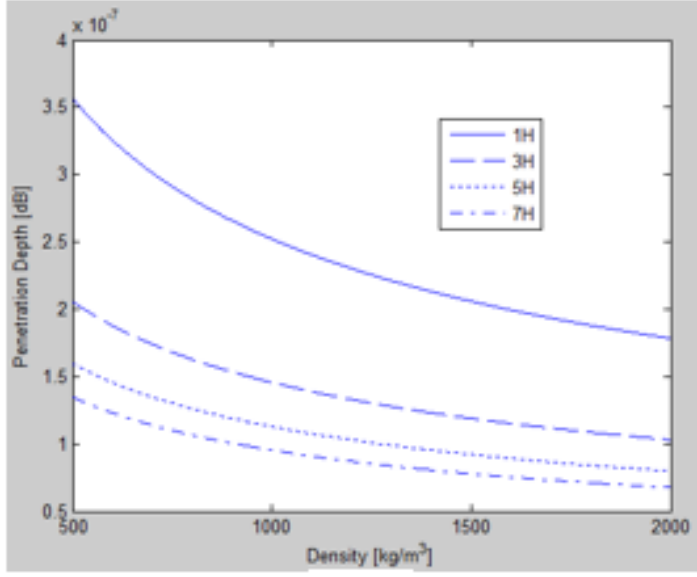

(C)

Fig. 10. (A, B) Effect of the changes in the film density to MTSM response with the viscosity is 0.001 ; (C) Penetration depth of MTSM as a function of with the viscosity is 0.001 


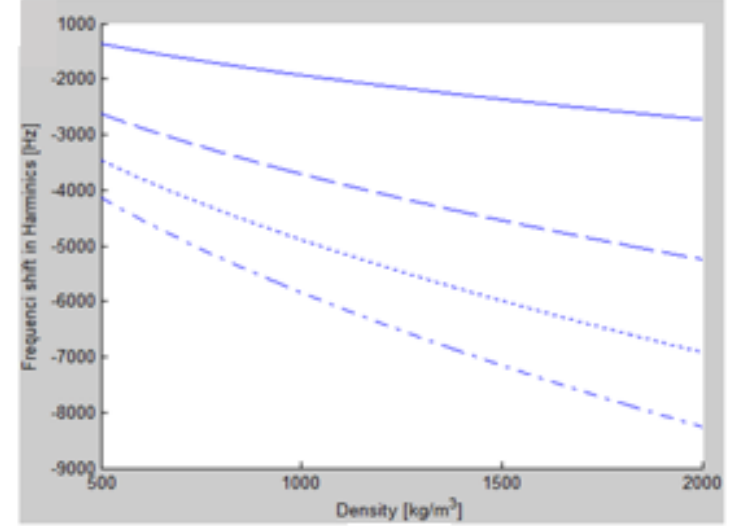

(A)

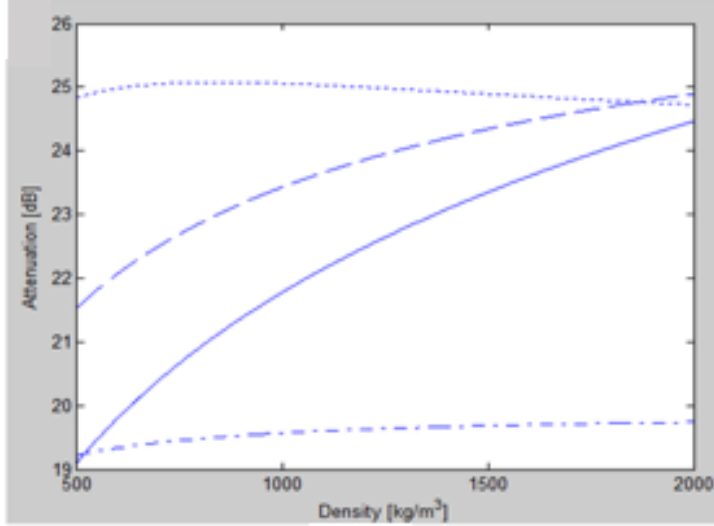

(B)

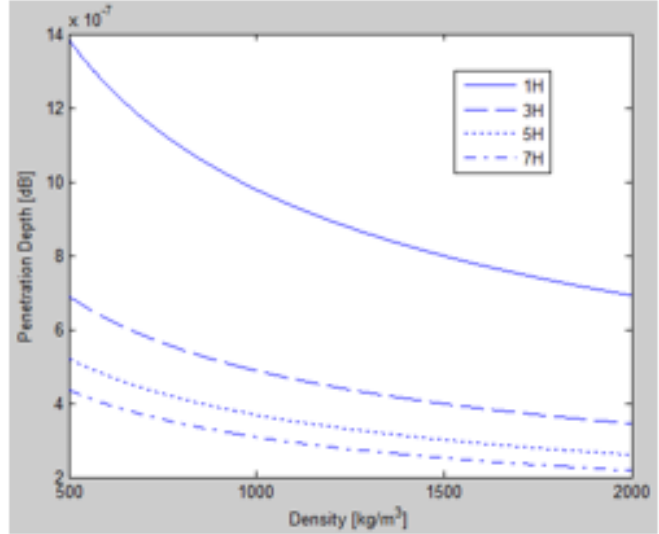

(C)

Fig. 11. (A, B) Effect of the changes in the film density to MTSM response with the viscosity is 0.01 ; (C) Penetration depth of MTSM as a function of with the viscosity is 0.01

In Fig. 12, the thickness of the VE film is always much smaller than the penetration depth of the film, except the $7^{\text {th }}$ harmonic. At $1^{\text {st }}, 3^{\text {rd }}$, and $5^{\text {th }}$ harmonics, the graphs show the typical Sauerbrey Mass effect. At the $7^{\text {th }}$ harmonic, as the density increases, the penetration depth of the MTSM sensor becomes close to the thickness of the film and this causes the oscillatory behavior of the MTSM sensor.
Frequency shift results are compared with those of Carine Galli Marxer [4] in the case of the density change and thickness change of film. Results of Carine Galli Marxer is about -1870 to $1260 \mathrm{~Hz}$, results of this research are about -2000 $\mathrm{Hz}$ to $-1000 \mathrm{~Hz}$ depending on the value of thickness or density, so this results can be accepted 


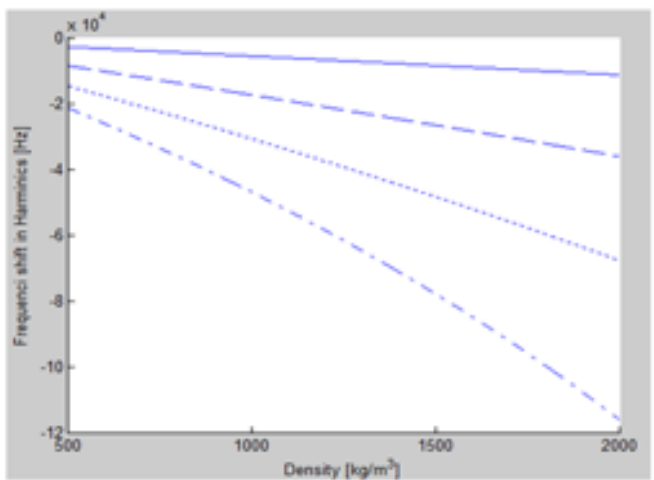

(A)

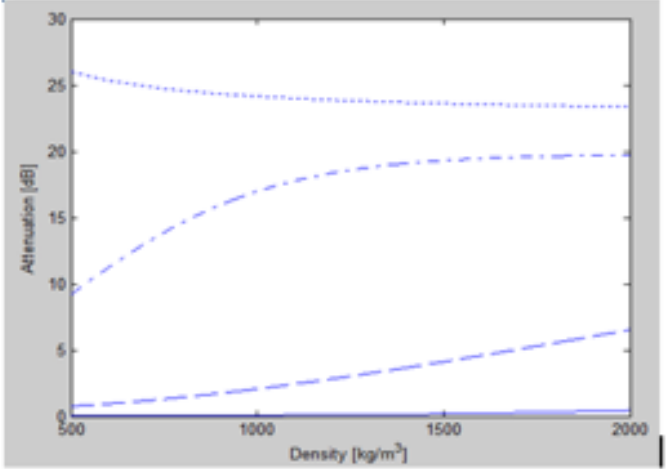

(B)

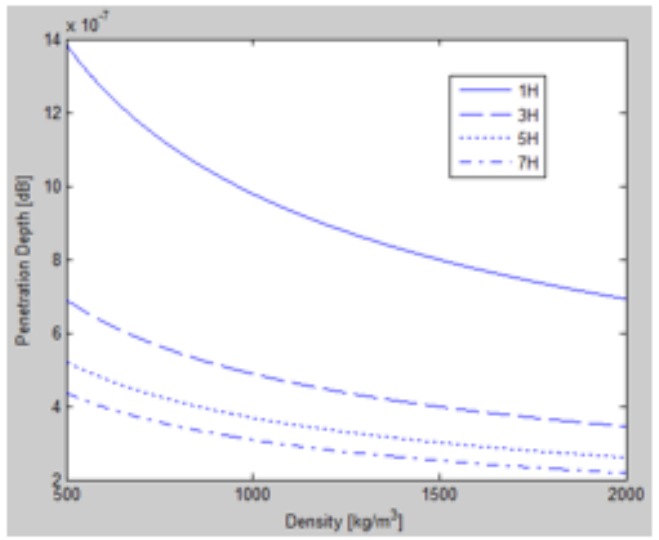

(C)

Fig. 12. (A, B) Effect of the changes in the film density to MTSM response with the viscosity is 0.1 ; (C) Penetration depth of MTSM as a function of with the viscosity is 0.1

\section{CONCLUSION}

The relationships between the shear wave and the observed behavior of electrical properties of loaded QCM have been illustrated. The strong damping of the shear wave in liquids allows the use of the QCM in liquid media by limiting the losses.

The comparation of the value of the penetration depth and the thickness of the film, the simulation results show that the behaviors of
MTSM sensor are the same with Sauerbrey and Kanazawa effect.

The relationships between the frequency shift, the attenuation of MTSM sensor and the thickness, density of film at harmonics have been illustrated. A knowledge of the properties of the loaded film is very useful in explaining the result of electrical properties measurements. This result will help choosing suitable polymers in fabrication and application QCM as biosensor. 


\section{Mô phỏng tính chất điện của linh kiện vi cân tinh thể thạch anh bằng kỹ thuật cộng hưởng đa hài dạng sóng trượt bề dày}

- Trần Thị Minh Thư

- Trần Huy Thông

- Dương Tấn Phước

- Ngô Võ Kế Thành

- Nguyễn Đăng Giang

Trung tâm Nghiên cứu và Đào tạo Thiết kế Vi mạch, ĐHQG-HCM

- Trương Hũu Lý

Trung tâm Nghiên cứu Triển khai - Khu Công nghệ cao Thành phố Hồ Chí Minh

\section{TÓM TẮT}

Linh kiện vi cân tinh thể thạch anh (QCM) úng dụng trong hóa hoc, lý sinh, vi sinh họ và linh kiện điện tủ đã được phát triển mạh mẽ trong nhũng năm gần đây. Trong bài báo này, mô tả các tính chất của cảm biến QCM (một hệ thống bao gồm linh kiện $Q C M$ và lớp màng mỏng đàn nhớt) hoạt động trong dãi tần số $5 \mathrm{MHz}$ đến 35 MHz của cộng hưởng đa hài dạng sóng truợt bề dày (MTSM, $n=1,3,5,7)$. Chúng tôi tính toán nhũng thay đổi cả về tần số cộng huởng và sư suy hao của linh kiện QCM. Bề dày lan truyền của sóng ngang tù̀ thạch anh vào lớp màng mỏng có giá trị khác nhau với nhũng hài khác nhau, tù đó suy ra các tính chất của màng mỏng hấp phu trên bề măt. Các hoạt động đa hài của linh kiện QCM được phân tích để thu thập các tính chất của màng mỏng hấp phu trên điện cưc của QCM. Điều này cho phép một "kỹ thuật lát mỏng ảo" bởi vì trên cùng một loại vật liệu thì độ sâu lan truyền của mỗi hài cũng khác nhau. Các phân tích lý thuyết của MTSM đã được phát triển để mô hình hóa và mô phỏng các dấu hiệu phản hồi của cảm biến tại tần số của các bậc hài. Dấu hiệu của quá trình lắng đọng trên bề mặt linh kiện QCM được xác định bằng cách nghiên cứu ảnh huởng của độ dày và độ cúng của môi trường.

Key words: linh kiện vi cân tinh thể thạch anh, cộng hưởng đa hài của mode (dạng) sóng truợt bề dày

\section{REFERENCES}

[1]. G. Sauerbrey, Use of quartz vibration for weighing thin films on a microbalance, $Z$. Phys., 155, 206-222 (1959).

[2]. K. Keiji Kanazawa, Mechanical behavior of films on the quartz microbalance, Faraday Discuss., 107, 77-90 (1997).

[3]. L. Rodriguez-Pardo, J. Farina, C. Gabrielli, H. Perrot, R. Brendel, Piezoelectric Transducers and Applications, Sensors and Actuators, B123, 560-567 (2007).

[4]. Carine Galli Marxer, Cell spreading on Quartz Crystal Microbalance elicits positive frequency shifts indicative of

viscosity changes, Anal. Bioanal. Chem., 377, 578-586 (2003).

[5]. C. Lu, O. Lewis, Investigation of filmthickness determination by oscillating quartz resonators with large mass load, $J$. Appl. Phys., 4385 (1972).

[6]. M.S. Hamid, Quartz Crystal Microbalance/ Heat Conduction Calorimetry (QCM/HCC), a new technology capable of isothermal, high sensitivity, mass and heat flow measurements at a solid/gas interface, Doctor of Philosophy, USA, 12-69 (2000).

Trang 204 
[7]. S.J. Kwoun, Doctor of Philosophy, Belgium (2006).

[8]. A.L. Briseno, High-performance organic single-crystal transistors on flexible substrates, Advanced Materials, 18, 17, 2320-2324 (2006).

[9]. F. Yamashita, Characterization and subcellular localization of KCNQ1 with a heterozygous mutation in the $\mathrm{C}$ terminus, J. Mol. Cell. Cardiol., 33, 2, 197-207, (2001).

[10]. D.S. Hibbett, A higher-level phylogenetic classification of the Fungi, Mycological Research, Elsevier Ltd., 111, 509-547 (2007).

[11]. R. Linder, Generation of classification criteria for chronic fatigue syndrome using an artificial neural network and traditional criteria set, In Vivo, 16, 1, 37-43 (2002).

[12]. Park, Antimutagenic Effect of Extract of Eleutherococcus senticosus Maxim, Korean Journal of Food Science and Technology, 34, 6, 1110-1114 (2002).

[13]. Takada, Phase III study of concurrent versus sequential thoracic radiotherapy in combination with cisplatin and etoposide for limited-stage small-cell lung cancer: results of the Japan Clinical Oncology Group Study 9104, J. Clin. Oncol., 20, 14, 3054-60 (2002).

[14]. R.M. Anderson, Manipulation of a nuclear NAD+ salvage pathway delays aging without altering steady-state NAD+ levels, J. Biol. Chem., 277, 21, 18881-90, (2002).

[15]. Hamada, The Transport of Prolamine RNAs to Prolamine Protein Bodies in Living Rice Endosperm Cells, Plant Cell, 15, 10, 2253-2264 (2003).

[16]. J. Plunkett, An Evolutionary Genomic Approach to Identify Genes Involved in Human Birth Timing, Journal. Pgen., 7, 4, 1-10 (2011).
[17]. C. Lin, Molecular Phylogenetics and Evolution of Maternal Care in Membracine Treehoppers, Society of Systematic Biologists, 53, 3, 400-421 (2004).

[18]. E. Heuberger, The Impact of Natural Odors on Affective States in Humans, Chem. Senses, 33, 441-447 (2008).

[19]. C.R. Cook, Predictors of Bullying and Victimization in Childhood and Adolescence: A Meta-analytic Investigation, School Psychology Quarterly, 25, 2, 65-83 (2004).

[20]. Lojou and Bianco, Membrane Electrodes for Protein and Enzyme Electrochemistry, Electroanalysis, 16, 13-14 (2004).

[21]. L.M. Notley, Characterization of the human cytochrome $\mathrm{P} 450$ forms involved in metabolism of tamoxifen to its alphahydroxy and alpha,4-dihydroxy derivatives, Chem Res Toxicol, 18, 16111618 (2005).

[22]. K.M. Evans-Nguyen, L.R. Tolles, O.V. Gorkun, S.T. Lord, M.H. Schoenfisch, Interactions of thrombin with fibrinogen adsorbed on methyl-, hydroxyl-, amine-, and carboxyl-terminated self-assembled monolayers, Biochemistry, 44, 15561-8, (2005).

[23]. H.H. Yin, S.B. Ostlund, B.W. Balleine, Reward-guided learning beyond dopamine in the nucleus accumbens: The integrative functions of cortico-basal ganglia networks, Eur J Neurosci, 28, 8, 14371448 (2008).

[24]. Otzen, Kristensen, Oliveberg, Designed protein tetramer zipped together with a hydrophobic Alzheimer homology: A structural clue to amyloid assembly, Proc. Natl. Acad. Sci., 97, 9907-9912 (2003).

[25]. D. Filliard, Investigation by QCM of the Specific and Nonspecific Avidin Interaction onto a Biotinylated Polypyrrole 
Film, Electroanalysis, 16, 8, 667-673 (2004).

[26]. B. He, B. Topper, P. Hobert, Heparan sulfate proteoglycan-dependent induction of axon branching and axon misrouting by the Kallmann syndrome gene kal-1, Proc Natl Acad Sci, 99, 6346-51 (2002).
[27]. B. Lin, M. Hua, Y. Zhang, W. Zhang, L. Lv, B. Pan, Effects of organic acids of different molecular size on phosphate removal by HZO-201 nanocomposite, Chemosphere, 166, 422-430, (2003a).

[28]. W. Zhou, et al, Global analyses of sumoylated proteins in Saccharomyces cerevisiae. Induction of protein sumoylation by cellular stresses, J. Biol. Chem., 279, 31, 32262-8 (2004). 